Michael W. Yarbrough

Yale University, USA

https://doi.org/10.18778/1733-8077.09.1.02

\section{When Symbolic Action Fails: Illustrations from Small-Claims Court}

Abstract This article extends the cultural-pragmatics model of symbolic action developed by Jeffrey Alexander and his associates, which observes that symbolic action has become difficult in contemporary, highly differentiated societies. When symbolic action succeeds, the cultural-pragmatics approach argues it does so by re-"fusing" the elements of social performance, which have been disaggregated by the effects of social differentiation. Fusion produces affectively charged shared interpretations with the power to reshape the social world in important ways. Drawing on an example from my own ethnographic research, I argue that the current articulation of cultural pragmatics is unable to apprehend instances when such affectively charged shared interpretations are produced even when the actor or actors in a performance fail to achieve their performative goals. In this article I introduce the concept of "meta-performance" as a tool for analyzing such instances, arguing that this enables us to consider interpretive vantage points that are not conditioned by the actor's intent. I then apply my extended meta-performative model to the ethnographic episode that inspired it. This bitterly fought court case between an adult daughter and her family produced a shared feeling among those assembled of hopeless deadlock between the family members, drawing a series of sharp symbolic boundaries - inter alia, between the daughter and her family and between "love" and "money" - not only despite, but precisely because all the participants' component performances failed.

Keywords Cultural Pragmatics; Cultural Sociology; Family; Litigation; Social Differentiation; Social Performance
$1 /$ 3,500 or nothing!" barked the frail wom$\$$ an, surrounded by her family one spring morning in a New England small-claims court. According to Eleanor D'Agostino, her daughter Jill ${ }^{1}$ had stolen twice this amount from Eleanor's safety deposit box while she lay convalescing in Jill's home. Jill had already given her mother the other half of the disputed $\$ 7,000$, essentially ad${ }^{1}$ All names in the ethnographic passages of this article have
been changed. been changed. mitting her guilt. Would the court please finally return the rest?

But, Jill claimed she stole nothing. Upon her sister Mary's instructions, she spent all that money on her mother's care, a time she beseechingly described to the court with an itemized list of not only expenses she paid for her mother, but also care she performed. The $\$ 3,500$ she had already paid expressed not her guilt, but her good-faith attempt to reconcile with her family. She was happy to forfeit some money. She asked only that her healing efforts be recognized in the form, naturally, of a favorable verdict.

Judge Deluca was flummoxed. This should not be about money, she pleaded, but about love. "They all love you very much," she told Eleanor. "They just have different ways of showing it. Heal your wounds."

But no wounds healed that day; mother and daughter departed as deadlocked as they had entered. Deluca withheld immediate judgment, while the audience (including me) quizzically wondered whom to believe. Thus, the riveting and galling drama of the trial slunk out the door to a confusing and heartbreaking end. The final verdict, delivered weeks later, awarded the mother about half of her full claim. In the end, despite her all-or-nothing ultimatum, Eleanor received neither $\$ 3,500$ nor $\$ 0$, but a confusing amount in between.

\section{***}

This vignette displays several characteristic features of symbolic action in contemporary, highly differentiated societies. Multiple symbolic actors (mother, daughter, judge) pursue their own agendas while participating in and observing the others' performances, enacting a drama interpretable from many vantage points, yet recognizably organized within the distinctive genre of the trial. Propelled by the combustible mixture of economy and intimacy (Zelizer 2005), the drama asks: Who handled this dangerous mixture most appropriately? But, the trial limps to a confusing anticlimax rather than a clear answer, yielding an unmistakable hopelessness.

In this paper I use this vignette drawn from my own ethnographic research to identify and push beyond a major limit of the cultural pragmatics theory of symbolic action in contemporary, highly differentiated societies (Alexander, Giesen, and Mast 2006). A wide range of theorists have long noted that coherent and moving symbolic experiences are less common today than in the simpler, more centrally ritualistic societies of the past, although just how common remains vigorously debated (e.g., Benjamin 1968; Lukes 1975; Turner 1975; 1982; Jameson 1991; Phelan 1993; Baudrillard 1995; 2007; Weber 2001; Alexander 2003; Horkheimer and Adorno 2007). ${ }^{2}$ Virtually all these otherwise diverse scholars attribute this symbolic thinning to social differentiation in one form or another. The cultural-pragmatics paradigm attempts to specify the causal links between the two phenomena by framing contemporary symbolic actions as performances that, if they are to succeed, must re-"fuse" the elements of performance that have been sundered by social differentiation.

In the terms of cultural pragmatics, the above vignette would typically be dismissed as a collection of unquestionably failed performances, since all the actors failed to portray themselves in the light they desired to their audience. Such an assessment would ig-

${ }^{2}$ Many scholars have rightly criticized romanticized and overly simplistic scholarly accounts of older societies (Said 1979, Mohanty 1991; Sherwood 1994; Legg 2005). It nonetheless remains uncontroversial that the enormous complexity of contemporary societies profoundly shapes, and usually frustrates, symbolic action's possibilities. 
nore, however, the significance of the clear collective feeling of dismay at the family's apparently permanent estrangement, one that warned of the dangers of mixing love with money. In other words, despite the performances' failures - indeed, because of them a powerful symbolic experience was produced. Such a case presents a puzzle for cultural pragmatics as currently articulated, for in its current terms only successfully fused performances can produce shared interpretations. In this paper I redevelop and extend the cultural-pragmatics paradigm to make it capable of addressing such instances of fusion-through-failure. My intervention suggests that there always coexist many interpretive vantage points from which social actors can and, more importantly, do interpret any given symbolic action. An action may achieve coherence from one or more of these vantage points even when it fails to achieve the actor's or actors ${ }^{\prime 3}$ desired effect. I suggest reserving the language of performance for analysis from the actor's intent vantage point and introduce the new concept of "meta-performance" for analysis from other vantage points less directly conditioned by the actor's intent. I propose that these various vantage points are often interpretively linked in complex ways that demand greater understanding.

I begin by briefly summarizing the cultural-pragmatics model in the context of broader debates in cultural sociology. I then introduce the concept of meta-performance and explain its utility vis-àvis the problem outlined above. In the subsequent section, I apply this expanded cultural-pragmatics model to a fuller account of the vignette that opened the article, analyzing in detail how the

${ }^{3}$ For the remainder of this article I use the singular "actor" to refer both to individual actors and to groups acting together according to the same basic agenda, and the plural "actors" to refer to individuals or groups following distinct agendas. case instilled a shared sense of hopeless deadlock through each performer's failure to symbolically dominate the proceedings and produce a more conventionally coherent narrative. Finally, I reflect on the model's application, suggesting directions for further development.

\section{Cultural Pragmatics and the Contin- gency of Symbolic Action}

It has become commonplace to note that contemporary symbolic action often falls short of coherence, to say nothing of transcendence. Miscommunication, mistrust, and cynicism are widespread (Alexander 2006a:30). Interpretations differ from one group or one individual to the next, often becoming embroiled in fierce contestation (e.g., Charlesworth 1994; Chesters and Welsh 2005; Pickerill and Webster 2006). As opposed to ancient societies' relative homogeneity and unity, contemporary societies are cross-cut by infinite social groups and elaborated into such distinct domains as religion, family, work, and politics (Walzer 1983), forcing symbolic action onto a profoundly more complex social terrain.

But, despite its relative retreat, meaningful symbolic action continues to lace through our collective lives. Families joyfully cry together at weddings and angrily attack each other at divorce hearings. Charismatic politicians inspire coalitions to hope and crowds to rage (Alexander 2010). While reflexive self-hood and proliferating interpretive communities virtually foreclose the possibility that any given symbolic action will identically move all people for the same reason, nonetheless symbolic action does sometimes find a shared audience, however partial. Thus, adequate accounts of contemporary symbolic action must accommodate both symbolic failure and symbolic success.
The Power of Cultural Pragmatics: Social Differentiation as a Not-Insurmountable Constraint on Symbolic Action

The cultural-pragmatics model of social performance is especially well-suited to this task. Alexander argues that, to project meaning into an audience, successful symbolic action must "fuse" social performance's different elements. Under contemporary conditions these elements include:

1. the systems of collective representation within which the actor's motivation and meaning are potentially intelligible by the audience, including both the deep background semiotic vocabulary and the more immediate script which a fused performance will be perceived to have followed;

2. the actor(s) whose actions encode these representations;

3. the observers who attempt to interpret the action;

4. the material objects (including the setting);

5. the actor's actions, which spatially and temporally order the narrative, called the mise-en-scène (literally, "putting into the scene"); and

6. the social power that conditions an actor's access to the symbolic and material means of production and the scope of permissible interpretations (Alexander 2006a:32-37).

A fused performance is one in which these various elements merge into apparent seamlessness and achieve "flow," as the audience focuses all its interpretive powers on the performance as intended by the actor (Csikszentmihályi 2000; Alexander 2006a).

Fusion's opposite - failure - is possible because the elements of performance are now relatively autonomous from one another. For example, actors may perform a familiar script in an unexpected setting, as in the numerous contemporary Shakespearean performances set not in Elizabethan England, but in war- torn Vietnam or American suburbia. Such choices may not yield a moving and intelligible performance, but - importantly - they sometimes do. That such choices are not only possible, but also sometimes both coherently and movingly understood demonstrates just how autonomous the elements of performance have become. In extremely undifferentiated societies, by contrast, performative elements were often not merely interpretively linked, but completely identified with one another. The ritual dancer did not just portray a god, for example; he was that god (Lévi-Strauss 1963; Turner 1969; Mauss 1990). Performative failure was literally unthinkable.

Competing Models of Contemporary Symbolic Action: Total Success or Total Failure

One line of cultural theorizing tends to imply a similarly high success rate for symbolic action in contemporary societies, albeit for different reasons. The "tool kit" model of culture, most fully developed by Ann Swidler (1986), argues that culture provides a tool kit of "strategies of action" from which people select (albeit not usually very deliberately) those most likely to help them solve some problem. Importantly, not all people can succeed with the same strategies; a Wall-Street banker and a Queens auto mechanic cannot easily trade places, and they cannot easily use the tools in each other's kits. But, in most cases people will tend to choose from among the strategies that are available to and most likely to work for them, with almost intuitive pragmatism. Thus, in practice, we should generally expect most attempted symbolic actions to succeed. ${ }^{4}$

${ }^{4}$ The cultural-pragmatics model resembles the tool kit model in assuming that actors choose certain performative elements from among an array of meaningful possibilities because of their perceived fit. But, the tool kit model implies that inapt components are usually eschewed preemptively, while the cul-
tural-pragmatics model assumes such misfits are common. 
A different line of theorizing suggests the opposite: Because our worlds are increasingly complex, they are now so bereft of true meaning that symbolic action always fails. Most prominently occurring under the banners of the Frankfurt School (Horkheimer and Adorno 2007) and of post-modernism (Jameson 1991; Phelan 1993; Baudrillard 1995), this line of thought argues that the mediations wrought by contemporary social differentiation - often, more specifically, by capitalism in its various forms have pushed authentic meaning off the stage entirely. One can play with meaning, but one can never deeply and authentically experience it in the way of our nostalgically remembered forefathers. We live in the age of disenchantment.

Cultural pragmatics counters the total-success and total-failure arguments with an emphasis on contingency. When the elements of performance align, successful symbolic action results. When they do not, it fails. By analyzing how such contingency actually plays out, cultural pragmatics promises to explicate social differentiation's influence on symbolic action more fully.

\section{Extending Cultural Pragmatics: "Success" on Terms Other than the Actor's Own}

As the name suggests, the cultural-pragmatics paradigm typically judges fusion or failure against the actor's desired outcome (even though this goal may not always be crisply defined or consciously articulated). For example, the Republican Party of the 1990's wanted the American public to see President Bill "Slick Willy" Clinton as a law-breaking womanizer, while the Clinton White House wanted them to see Republicans as a time-wasting, moralizing "vast rightwing conspiracy" (Mast 2006). South Africa's Truth and Reconciliation Commission attempted to repair the trauma of apartheid and lay the basis for democratic solidarity (Goodman 2006). German Chancellor Willy Brandt may not have consciously planned to enact a newly penitent German identity when he knelt before the Warsaw Memorial to Jewish Holocaust Heroes, but his gesture undeniably embodied his apparent desire to express remorse (Rauer 2006). ${ }^{5}$

This focus on the actor's intent is extremely useful especially given the cultural-pragmatics approach's central concern with the "ritual-like" subset of symbolic actions whose grand scale and transcendent experience virtually require at least a nominally intentional director. But, ritual-like fusion forms but a small part of the outcomes yielded by symbolic actions. What cultural-pragmatics scholarship has yet to engage is that large set of symbolic outcomes not directly indexed to the actor's pragmatic intent. This is not an inconsequential oversight. In purely quantitative terms, perhaps the bulk of symbolic interpretations that circulate in the world have little to do with the intent of those who performed the interpreted actions. At a minimum, this suggests that the category of "fusion" as currently articulated is leaving out a great deal of shared and consequential symbolic experience. If the category cannot be expanded to incorporate such experience, this raises doubts about the concept's utility.

I argue that the concept of fusion can be expanded if the associated model of symbolic action is complexified to incorporate attention to what I call the "meta-performance." A symbolic action is a fused

${ }^{5}$ As this last example shows, often the most successful per-
formances are those which do not appear to intend to be suc formances are those which do not appear to intend to be successful performances as such, because this apparent lack of intention creates a sense of authentic (versus self-serving, for
example) motivation (Alexander and Mast 2006:4-7). But, this authentic motivation then becomes part of the performance' central meaning. meta-performance, I argue, insofar as it achieves in at least part of its audience a shared, coherent, and often affectively registered understanding of the action's meaning, but when that meaning does not impute a direct identity between the actor's intent and the audience's experience. This is a more relaxed notion of fusion than that typically used in culturalpragmatics scholarship, not only because it excludes the actor, but also (and relatedly) because it does not require quite the intensity of inter-subjective flow characteristic of pure, performative fusion. It nonetheless significantly exceeds the total lack of communication implied by "failure."

The language of meta-performance also better enables us to analyze overlapping performances by distinct actors touching on a shared topic. Examples range from the job interview and the blind date to more competitive situations, such as the political debate. Jason Mast's analysis (2006) of the Clinton-Lewinsky controversy considers the latter category, arguing that the success of the Clinton White House's performance helped congeal the overall battle between them and the Republican Party's counter-performance (Alexander 2006b) into an "event." Like "meta-performance," Mast's language of "event" recognizes multiple, interlinked interpretive levels, in Mast's case between the Clinton White House's performance and the Lewinsky episode's eventness. My proposal extends Mast's, however, by enabling inquiry into a range of possible articulations between the performative and meta-performative levels, beyond only that identifying meta-performative with performative success. For example, as I argue below, the central vignette of this paper links meta-performative fusion with all actors' performative failure. Exploring the range of possible articulations between performative and meta-performative levels of interpretation could be the central project of the extended cultural-pragmatics model I advocate here, a theme to which I return in the final section. For now, I illustrate the utility of this extended model by returning to the vignette that opened this paper.

Applying the Expanded Social-Performance Model: A Case of Intimate Litigation

I first encountered this vignette as part of ethnographic research I was conducting into small-claims disputes among litigants with pre-existing, affective relationships - friends, family, romantic partners, exes, and so on. I wished to understand better the ways people translated the problems of their everyday lives into legal problems. Small-claims hearings were a good site for exploring this question because most individuals represented themselves in public proceedings without the assistance of an attorney. This allowed me to access and observe directly some processes of legal translation. I embarked on three months of observing the weekly small-claims docket in the courthouse of a small New England city. I sat unobtrusively taking notes in the audience each week, which was mostly otherwise composed of the participants in upcoming cases for that day.

Cultural pragmatics emerged as a useful paradigm for making sense of my observations, for the litigants' actions in the trials were quite readily understandable as performances, but also quite often clearly failed to convey the impression that the litigant desired. What was difficult to square with cultural pragmatics was the coexistence alongside this repeated performative failure of an often intensely and tumultuously emotional atmosphere. Upon reflection it seemed to me that such conjunctures between performative failure and shared emotional 
experience occurred with some frequency even in settings beyond my formal research. Either these observations falsified cultural pragmatics, or the theory required further elaboration in order to be capable of apprehending such phenomena. It is this insight that led me to undertake the theoretical work outlined in the previous section.

I choose this particular vignette not only because it formed my most vivid reference point when thinking through my theoretical work, but also because it demonstrates my points with particular clarity. As such, it is by definition not a typical instance of the litigation I observed, let alone of fusion-through-failure more broadly. Many failed symbolic actions do not produce as intensely emotional and clearly shared interpretations as happened in this instance. More research on such instances will be necessary in order to explore precisely where the boundaries of metaperformative fusion lie, and how failed performances sometimes provoke such fusion and sometimes do not. In other words, while the example I use here is sufficient to demonstrate the need for complexifying the cultural pragmatics model and expanding its notion of fusion, this example alone cannot identify just how far that notion can and should be stretched. That limitation should be addressed in future work; for now, my theoretical intervention and the case that inspired it are useful precisely because they move cultural-pragmatics scholarship further in that direction. In addition to the theoretical limitations I outline above, existing cultural-pragmatics scholarship has been methodologically limited primarily to cases of performative success and overwhelmingly to grand events of national and international scale. In addition to its focus on performative failure, this case unfolds on a more everyday, intimate scale that deserves greater attention.
I argue that the case of the D'Agostinos entailed a series of performative failures that together composed a broader meta-performative outcome in which the improper mixing of love and money is perceived to have driven the family apart. The meta-performance re-separates love from money and, not coincidentally, differentiates one daughter, Jill, from the rest of her family into the status of stranger. The love-money mixture at the case's heart requires everyone to carefully balance their familial with their financial and legal roles, so all the courtroom performances intertwined both familial and legalistic background representations. While these background representations do not mandate complete separation between the intimate and the legal/financial realms, they do mandate that any intersections between these domains take particular, carefully managed forms (Zelizer 2005). Improper alignment with these background expectations was the major reason for each component performance's failure.

To recap, in this case Eleanor D'Agostino and her daughter, Mary D'Agostino Lawler, sued another of Eleanor's daughters, Jill D'Agostino, for $\$ 3,500$ of $\$ 7,000$ removed from Eleanor's safety deposit box while Jill cared for her. Jill countered that she removed the money on Mary's instructions and spent all of it on her mother's care. Judge Deluca presided, ultimately awarding the plaintiffs about half of their full claim in a judgment delivered later by mail. I first discuss each of the component performances, then turn to the meta-performance which they compose.

\section{The Failed Performance of Defendant/Daughter Jill}

Deluca spent about fifteen minutes reading the file before taking testimony, during which the elder D'Agostinos scowled at Jill and whispered amongst themselves (a scene I discuss at greater length be- low). After her perusal, Deluca turned immediately to Jill with a series of questions, skipping the plaintiffs entirely. Attempting to portray herself as both a good daughter and a responsible financial and legal actor, Jill began by submitting an itemized list of care-related expenses on which she claimed to have spent the disputed $\$ 3,500$.

Thus far her performance drew primarily on legalistic background representations, deploying the trope that, in the legal world, paper is more credible than the spoken word (Ewick and Silbey 1998:100). Deluca immediately understood Jill's purpose in submitting it, but some of the listed items triggered her suspicion and ultimately derailed Jill's entire performance. These included not only expenses such as Jill's attorney's fee and rent for the time her mother lived with her, but also Jill's caring tasks themselves, ranging from bathing and feeding Eleanor to clipping her toenails. Importantly, Deluca's response indicated doubt not only about these items' legal relevance, but also about Jill's daughterly character. She became increasingly sarcastic as she interrogated the list. "How is hiring an attorney your mother's expense?" she asked. Because it could have been resolved more easily, "in two letters," Jill replied. Was the rent actually agreed upon in advance, Deluca wanted to know, or was it "just some arbitrary number?" Was Jill expecting compensation for clipping her mother's toenails? No, Jill replied. "Well I'm glad you itemized these so I knew what you weren't charging her for," snapped Deluca. Judge Deluca's questions are part of her own performance, of course. Here, however, their sarcasm indicates that, for her, Jill's performance had become de-fused. Jill's performative mistake occurred in the dramatic choices she made when compiling the list, choices best understood as a kind of mise-en-scène conducted in advance of the performance. As with conventional mise- en-scène, Jill constructed the itemized list by spatially arranging signifiers, in this case on pieces of paper. While the overall technique of the itemized list was legible within the representational logic of the law, Jill's arrangement incorporated inappropriate signifiers, thereby de-fusing her entire performance.

Although legalistic in form, in content the submissions invoked more familial representations. Jill had included her attorney's fee, for example, because her mother and her sister had made this dispute excessively difficult. While she did not portray the alternative route they might have taken as particularly intimate ("two letters" rather than, say, one phone call) she was, nonetheless, blaming her excessively argumentative family for effectively forcing her to hire a lawyer. ${ }^{6}$ The legalistic list thus invoked a set of familial background representations portraying the legalization of intimate relations as driven by greed and unreasonableness (Engel 1984).

Whatever its performative purpose, the lawyer's fee was not recoverable and thus legally irrelevant. But, it was not this irrelevance alone that de-fused her performance, for small-claims litigants commonly request things not allowed by law, as one would expect in a court designed to assist non-expert litigants through the relaxation of procedural rules. Jill's more fundamental problem was that she sought legal credit for familial care, making her appear at least as greedy as her family. Within legalistic background representations the itemized list is most commonly read as a request for credit, as well as a legitimation of that request (Ewick and Silbey 1998). Judge Deluca clearly read it within this logic, dismissing Jill's de-

${ }^{6}$ Indeed, almost all intimate litigants I observed, including plaintiffs (who by definition initiate litigation), portrayed themselves as in court against their will. As in Jill's instance, I interpret this as invoking background representations of the normative boundaries separating affective intimacy from the law. 
nials of that purpose - at least for her care - as illogical. Why else would she list these items, if not to receive credit for them? In Deluca's eyes, the list of caring tasks disrupted the gendered familial script of the dutiful daughter Jill apparently intended to be driving the performance. Ironically, by attempting to demonstrate her daily sacrifice, she violated the very terms of that narrative as understood by Judge Deluca - and by members of the public audience assembled in the courtroom, who snickered as Deluca read out Jill's list. The work of a dutiful daughter is its own reward, not something for which one expects credit or compensation. She effectively appeared to be requesting financial compensation for acts of love, a mis-match (Zelizer 2005) that up-ended the delicate mixture of love and money lying beneath the case.

The Failed Performance of the Plaintiff D'Agostinos

While Jill's performative failure helped deliver a partially favorable verdict for her mother and sister, it did not ensure that their performance achieved fusion. Because the judge asked them few questions, their performance consisted primarily of non-verbal brio. During Judge Deluca's lengthy perusal of the claim at the beginning of the trial, Mary shook her fists in the air and grinned broadly at an audience member, while another sister scowled at Jill with half-lidded eyes. A friend of the family sympathetically rubbed mother Eleanor's back. Another friend, recognized by Deluca as an attorney, assured Deluca that she was there only as "amica," the legal jargon for "friend." Indeed, she was one of at least a dozen friends and family who accompanied the elder D'Agostinos to court, while Jill sat alone, but for her lawyer. The elder D'Agostinos' mutual support for each other, embodied in the caring gesture of the back-rub for the elderly mother, heightened the glare of their shared disdain for Jill. While Deluca never really gave them an opportunity to advance a more legal argument, their familial tableau suggested that the main script they wished to enact was for the family to stand publicly with their wronged mother in publicly shaming the greedy and duplicitous daughter. Indeed, Eleanor's forceful insistence that she wanted " $\$ 3,500$ or nothing!" was a stark ultimatum whose echoes of Patrick Henry implied stakes of moral principle, not monetary compensation.

As it turns out, Eleanor would not receive the full $\$ 3,500$ she demanded, presumably because Judge Deluca credited Jill for some of the items on her list. Meanwhile, their familial performance appeared even less successful in the eyes of both Deluca and the assembled audience. We all seemed saddened by their vitriol rather than moved by their righteous battle. Deluca lamented that "this clearly family matter" had to play out in public - in other words, that the plaintiff D'Agostinos had dragged Jill into court, whatever her faults may have been. She closed the hearing with a lengthy monologue pitched entirely in the vocabulary of family and interpersonal intimacy. As paraphrased in my notes, she said:

[e]veryone at this table believes they are doing the right thing. Everyone loves their mother very much, and wants nothing more than to make the last years of her life as comfortable as possible. They all love you, they just show it in different ways. I hope that the rifts that this has opened up can be healed and that you can come back together as a family. Heal your wounds.

As with her reaction to Jill above, this monologue forms part of Deluca's own performance, whose ultimate failure I analyze below. Here, however, it indicates the failure in her eyes of the plaintiffs' performance. Indeed, it addressed them almost exclusively.
"[The daughters] all love you," she told Eleanor, despite her previously obvious contempt for Jill's purportedly loving behavior. Whatever Jill's faults, her family's obstinacy now threatened their intimacy. That they had moved it from the protected, private realm of the family where it belonged into the harsh, public world of the courtroom disturbed Deluca greatly (Lasch 1977; Merry 1990). Much as Jill's request to be credited for her care, the other D'Agostinos vindictive glee undercut their claim to the familial high ground.

\section{The Failure of Judge Deluca}

The D'Agostinos were trapped in a dyadic drama in which every actor appealed to familial representations (at times intertwining them with legalistic background representations) to argue that they were good family members and their opponent(s) bad family members, thus appealing to a common code of good versus bad familial behavior while sorting themselves into that code in diametrically opposed ways (Alexander 2006b). With the above speech Deluca attempted to break this impasse with her legally authorized control of the courtroom stage, speaking in the familial language both parties shared, but attempting to redefine the meaning of love so as to permit everyone to be seen as a good family member. Whatever the opponents may have thought of each other's behavior, Judge Deluca asked them to think instead of each other's intention. She appealed to the family as a place of understanding and forgiveness, to the concrete knowledge the D'Agostinos had of each other because of their longstanding intimacy. Yet, no dramatic scene of reconciliation followed. The litigants and their supporters sat quietly and unresponsively through the magistrate's monologue. At least one supporter let out a nasal sigh, apparently skeptical that Jill really did love her mother, or that love were enough to justify reconciliation. Perhaps sensing the failure of her performance, Judge Deluca resignedly announced that the parties would receive her decision by mail, ending the trial with a whimper.

\section{Fusion through Failure: The Trial as Meta-} -performance

While each party's legal performance can be said to have succeeded on some level - the plaintiffs' by winning most of what they requested, the defendant's by winning some of the offsets she claimed, the judge's by conducting the trial and ultimately issuing a decision without any doubts about her authority - none of these fused in anything beyond a very thin sense of the term. The familial performances of the three parties, meanwhile, were each in their own way obvious failures. Jill's good-daughter claim was undermined by elements of her mise-en-scène that were seen by the judge as inconsistent with the dutiful-daughter script. The elder D'Agostinos' wronged-mother claim was largely sustained, but, thanks to their vindictiveness, at the price of any good-mother claim. Instead, they appeared pettily eager to air dirty family laundry in public. Judge Deluca's attempts to play familial peacemaker failed largely because the elder D'Agostinos refused to play along.

But, despite the failure of each of these individual performances, I, and others in the audience, seemed to find the drama as a whole deeply affecting. My own reaction to the events as they unfolded was viscerally uncomfortable. At one point I put down my pen in embarrassment for the litigants. As the plaintiffs' gleeful performance dis-confirmed my fears, I resumed with continued unease. Around me audience members whispered to each other in quizzical tones, disbelieving the sad scene they were witnessing. There seemed so little cause for hope, each side so 
insistent on vindication that neither seemed morally credible. When Deluca's hortatory intervention failed to produce a resolution, the outcome seemed settled.

Whatever may have happened among the D'Agostinos after their intimate litigation, at the end of their trial it seemed that all of us in the room - the audience, Judge Deluca, and both parties - all shared a sense that the relationship between Jill and her family was now fundamentally defined by estrangement, having replaced the intimacy of a familial relationship with the distance of public strangers. Judge Deluca sighed and stared at her makeshift desk, melancholy over her, and the family's, failure. "So sad," whispered one audience woman to her companion. Another man let out a long, low whistle of disbelief. The plaintiffs, meanwhile, were energetic, even celebratory, pumping their fists in the air and smiling broadly. The cumulative failures of the component performances resulted, ironically, in a shared understanding among all of us about the nominal meaning of the event we had just witnessed. Insofar as the celebrating plaintiffs assigned a different moral significance to the event, the meta-performative fusion they experienced diverged from that which the rest of us experienced. But, everyone in the room seemed to have experienced some variety of fusion on this meta-performative level, signifying some sort of deeply felt, apparently coherent understanding of the event. It was, in the end, a near-ritual of excommunication.

As discussed above, any given performance might achieve any range of meta-performative outcomes, either on its own or in interaction with other performances. Of the many meta-performances one might have noted in the courtroom that day, the most important is this perspective on the trial as a whole. For one thing, this perspective constitutes the terrain upon which the performances took place. The genre of the trial, with its employment of adjudicated competition, is intrinsic to the courtroom setting. It leads one to expect resolution, one way or another. Such a perspective is further encouraged by the trial's triadic structure, in which the competition - the performance and counter-performance, in the terms of cultural pragmatics - is adjudicated by judge and jury, metonymically standing in for the broader public. Litigants would be familiar with this performative structure from countless courtrooms in literature, film, and television, perhaps especially from the mushrooming daytime court television shows whose format mimics small-claims court, with litigants representing themselves, and on which disputes among intimates comprise a notably large proportion of the docket (Kohm 2006). The familiarity of this performative architecture easily orients the component performances toward each other and encourages one to meta-performatively interpret the performances as a complete narrative with an ultimate outcome, in some sense independent of the individual performances while simultaneously composed of them.

The D'Agostinos' trial, however, produced not a clear winner, but a collection of undeserving ingrates. Instead of triumph, failure - of each of the participants and of the family relationship as a whole - became the meaning of the event. Of the three failures, Judge Deluca's most solidified the meta-performative fusion, her dramatic yet unsuccessful attempt at reconciliation narratively crystallizing the hopelessness of the situation. Meanwhile, the plaintiffs' failure is particularly interesting, for they got the estrangement they apparently desired, but in part through their performance's failure rather than its success. ${ }^{7}$ This suggests the link between pragmatic

${ }^{7}$ A successful performance could also have expelled Jill, but
performative success was unnecessary for doing so. performative success was unnecessary for doing so. and performative success may sometimes be looser than often acknowledged in cultural pragmatics.

\section{Conclusion: Toward a Research Program} in Meta-Performance

Thus, even within this one episode, we see a range of articulations between performative failure and metaperformative fusion. Moreover, we see the importance of articulations among overlapping performances in shaping the meta-performative. By more fully embedding the symbolic contingency already emphasized by cultural pragmatics into this complicated inter-performative architecture, we begin to appreciate exponentially more complex forms of contingency. Many questions remain, of course, and we can imagine several lines of potential future investigation.

First and most simply, what is the range of relationships that can exist between performative and metaperformative outcomes? Among the D'Agostinos we saw performative failures either encourage (plaintiff and defendant) or condense (Judge Deluca) metaperformative fusion. Are other relationships possible? For example, might there be situations in which performative success or failure is basically irrelevant to the meta-performative fusion that emerges, rather than closely linked as they were here and in Mast's discussion of the Lewinsky affair?

Second, we might focus on the elements of performance, asking whether different elements have particular roles to play in linking the performative with the meta-performative. For example, do certain background cultural representations, especially those which situate a performance within a particular genre, tend to assimilate pragmatic performative failure into meta-performative boundary fusion? Perhaps the background representation of the "stage performance" tends to invoke assumptions that the opera singer will attempt to perform as well as possible, an assumption which probably also attends the background representation of the "trial" genre. What specifically constitutes a "good" performance in each case would reference a genre-specific set of background representational criteria, of course, but these criteria will be meta-performatively confirmed when a performance in the given genre fails.

Relatedly, do particular architectures of overlapping performances tend to favor certain ways of linking the performance to the meta-performance? For example, when two or more actors compete with each other for communicative dominance, perhaps this architecture (as partially constructed, for example, by the background cultural representation of the "debate") tends to invoke meta-performative frames that closely identify one actor's failure with the other actor's success, so that there is a greater likelihood than in other situations that one performance will fuse and, by virtue of the meta-performative frame within which it occurs, to generate a more coherent meta-performative interpretation of the overall "event" (to use Mast's term).

Continuing with the theme of overlapping performances, we might ask how such situations generate meta-performative fusion even when all component performances fail, ashappened with the D'Agostinos. This is an especially salient question given the high likelihood of performative failure that has been emphasized throughout this article. In the D'Agostinos' case, this link crucially turned on the background representation of deadlock: Within such a narrative, there is no reason to expect future reconciliation when parties appear unwilling to compromise - an unwillingness dramatically underscored by Judge Deluca's failed attempt at breakthrough. The trope 
of deadlock actually assimilated the performative failures into an overarching narrative structure. But, a range of other meta-performative outcomes may be possible in a range of situations, of course, and these may relate to universal performative failures in distinctive ways as befit their own relevant background representations.

In short, by disaggregating meta-performance from performance proper, an extended cultural-pragmatics scholarship can examine not only each level's conditions of fusion and failure, but also these levels'

\section{References}

Alexander, Jeffrey. 2003. The Meanings of Social Life: A Cultural Sociology. New York: Oxford University Press.

Alexander, Jeffrey. 2006a. "Cultural Pragmatics: Social Performance Between Ritual and Strategy." Pp. 29-90 in Social Performance: Symbolic Action, Cultural Pragmatics, and Ritual, edited by Jeffrey Alexander, Bernhard Giesen, and Jason Mast. New York: Cambridge University Press.

Alexander, Jeffrey. 2006b. "From the Depths of Despair: Performance, Counterperformance, and «September 11»." Pp. 91-114 in Social Performance: Symbolic Action, Cultural Pragmatics, and Ritual, edited by Jeffrey Alexander, Bernhard Giesen, and Jason Mast. New York: Cambridge University Press.

Alexander, Jeffrey. 2010. The Performance of Politics: Obama's Victory and the Democratic Struggle for Power. New York: Oxford University Press.

Alexander, Jeffrey and Jason Mast (2006) "Introduction: Symbolic Action in Theory and Practice: The Cultural Pragmatics of Symbolic Action." Pp. 1-28 in Social Performance: Symbolic Action, Cultural Pragmatics, and Ritual, edited by Jeffrey Alexander, Bernhard Giesen, and Jason Mast. New York: Cambridge University Press.

Alexander, Jeffrey, Bernhard Giesen, and Jason Mast, (eds.). 2006. Social Performance: Symbolic Action, Cultural Pragmatics, and Ritual. New York: Cambridge University Press. inter-relation. This enables one to appreciate both the contingency of contemporary symbolic action and all its many complex consequences.

\section{Acknowledgements}

For comments on previous drafts of this paper I would like to thank Jeffrey Alexander, Elijah Anderson, Rafael de la Dehesa, Rachel Sherman, Philip Smith, and audiences at American Sociological Association, Law \& Society Association, Center for Cultural Sociology, and Northeast Law \& Society conferences.

Baudrillard, Jean. 1995. Simulacra and Simulation. Ann Arbor, MI: University of Michigan Press.

Baudrillard, Jean. 2007. In the Shadow of the Silent Majorities. New York: Semiotext(e).

Benjamin, Walter. 1968. Illuminations. New York: Harcourt, Brace and World.

Charlesworth, Andrew. 1994. "Contesting Places of Memory: The Case of Auschwitz." Environment and Planning D Society and Space 12(5):579-593.

Chesters, Graeme and Ian Welsh. 2005. "Complexity and Social Movement(s)." Theory, Culture \& Society 22(5):187-211.

Csikszentmihályi, Mihály. 2000. Beyond Boredom and Anxiety: Experiencing Flow in Work and Play. San Francisco, CA Jossey-Bass.

Engel, David. 1984. “The Oven Bird's Song: Insiders, Outsiders, and Personal Injuries in an American Community." Law \& Society Review 18(4):551-582.

Ewick, Patricia and Susan Silbey. 1998. The Common Place of Law: Stories from Everyday Life. Chicago, IL: University of Chicago Press.

Goodman, Tanya. 2006. "Performing a «New» Nation The Role of the TRC in South Africa." Pp. 169-192 in So- cial Performance: Symbolic Action, Cultural Pragmatics, and Ritual, edited by Jeffrey Alexander, Bernhard Giesen, and Jason Mast. New York: Cambridge University Press.

Horkheimer, Max and Theodor Adorno. 2007. Dialectic of Enlightenment. Stanford, CA: Stanford University Press.

Jameson, Frederic. 1991. Postmodernism, or, The Cultural Logic of Late Capitalism. Durham: Duke University Press.

Kohm, Steven A. 2006. “The People's Law versus Judge Judy Justice: Two Models of Law in American RealityBased Courtroom TV." Law \& Society Review 40(3):693-728.

Lasch, Christopher. 1977. Haven in a Heartless World: The Family Besieged. New York: Basic Books.

Legg, Stephen. 2005. “Contesting and Surviving Memory: Space, Nation, and Nostalgia in Les Lieux de Mémoire." Environment and Planning D: Society and Space 23(4):481-504.

Lévi-Strauss, Claude, (ed.). 1963. “The Sorceror and His Magic." Pp. 167-185 in Structural Anthropology. New York: Basic Books.

Lukes, Steven. 1975. "Political Ritual and Social Integration." Sociology 9(2):289-308.

Mast, Jason. 2006. "The Cultural Pragmatics of EventNess: The Clinton/Lewinsky Affair." Pp. 115-145 in Social Performance: Symbolic Action, Cultural Pragmatics, and Ritual, edited by Jeffrey Alexander, Bernhard Giesen, and Jason Mast. New York: Cambridge University Press.

Mauss, Marcel. 1990. The Gift: The Form and Reason for Exchange in Archaic Societies. New York: W. W. Norton.

Merry, Sally. 1990. Getting Justice and Getting Even: Legal Consciousness Among Working-Class Americans. Chicago, IL: University of Chicago Press.

Mohanty, Chandra. 1991. “Under Western Eyes.” Pp. 196220 in Third World Women and the Politics of Feminism, ed- ited by Chandra Mohanty, Ann Russo, and Lourdes Torres. Bloomington, IN: Indiana University.

Phelan, Peggy. 1993. Unmarked: The Politics of Performance. New York: Routledge.

Pickerill, Jenny and Frank Webster. 2006. “The Anti-War/ Peace Movement in Britain and the Conditions of Information War." International Relations 20(4):407-423.

Rauer, Valentin. 2006. “Symbols in Action: Willy Brandt's Kneefall at the Warsaw Memorial." Pp. 257-282 in Social Performance: Symbolic Action, Cultural Pragmatics, and Ritual, edited by Jeffrey Alexander, Bernhard Giesen, and Jason Mast. New York: Cambridge University Press.

Said, Edward. 1979. Orientalism. New York: Vintage.

Sherwood, Steven J. 1994. "Narrating the Social: Postmodernism and the Drama of Democracy." Journal of Narrative and Life History 4:69-88.

Swidler, Ann. 1986. "Culture in Action: Symbols and Strategies." American Sociological Review 51(2):273-286.

Turner, Victor. 1969. The Ritual Process: Structure and AntiStructure. Chicago, IL: Aldine.

Turner, Victor. 1975. Dramas, Fields, and Metaphors: Symbolic Action in Human Society. Ithaca, NY: Cornell University Press.

Turner, Victor. 1982. From Ritual to Theatre: The Human Seriousness of Play. New York: Performing Arts Journal Publications.

Walzer, Michael. 1983. Spheres of Justice: A Defense of Pluralism and Equality. New York: Basic Books.

Weber, Max. 2001. The Protestant Ethic and the Spirit of Capitalism. London, New York: Routledge.

Zelizer, Viviana. 2005. The Purchase of Intimacy. Princeton NJ: Princeton University Press. Yarbrough, Michael W. 2013 “When Symbolic Action Fails: Illustrations from Small-Claims Court." Qualitative Sociology Review 9(1):44-57. Retrieved Month, Year (http://www.qualitativesociologyreview.org/ENG/archive_eng.php). : 